\title{
Determinants \\ of managers' behaviour in a crisis situation in an enterprise - an attempt at model construction
}

Anna Walecka, Ph.D. Lodz University of Technology, Faculty of Management

\section{Introduction}

The emergence of a crisis in an enterprise as well as its course are often strongly dependent on various factors. These determinants are formed, among others, by elements of the external environment of the organisation and personality-related factors associated with the enterprise's managers.

The literature shows a number of ways to overcome a crisis. Typical anti-crisis measures include: rationalisation of the scope of the enterprise's activity through liquidation or merger of some subsidiaries, concentration of production capacities, sale of assets and reduction in fixed costs to obtain financial resources necessary to survive, undertaking of innovative actions, changes in technology in the area of business activity, appropriate shaping of interpersonal relationships (internal marketing) and relationships with entities in the environment (affiliate marketing), active participation of managers in the process of implementing changes, precisely defined roles of managers at all levels in the implementation of changes, monitoring of changes (comparing the performance to earlier forecasts), retention of the most valuable employees in 
the organisation, regular assessment of the enterprise's financial situation, as well as regular planning and conducting of strategic analyses (Malewska 2003, pp. 44-45).

As can be seen, managers in a crisis situation can take various remedial measures. These measures may be different. Managers may take very radical steps, focused on the future, or be extremely conservative and not make any important decisions, hoping that "the situation will resolve itself somehow".

The type of measures that will be taken depends primarily on the situation, the origins of the particular crisis, its type or stage of development. However, the pressure exerted by internal and external participants of the crisis, as well as personality traits of the managers, are also important.

Considering the above, the objective of the paper is an attempt to construct a model determining the behaviour of the management in a crisis situation ${ }^{1}$.

\section{Behaviours of managers of enterprises in a crisis situation}

In modern organisations, increasingly greater emphasis is placed on human resources, which have become the most important capital in an organisation. Thus, exploring the specifics of the behaviour of people in an organisation becomes an important field of management. This knowledge allows one to make the right decisions.

Due to the number of scientific fields involved in exploring the behaviour of people in an organisation, a clear definition is difficult to obtain. In psychology, behaviour is defined as the organism's way of adapting to the environment. Behaviour comprises the person's individual actions (Zimbardo 2005, p. 11). Other definitions ${ }^{2}$ indicate that behaviour is a coordinated action, taken in respect to a particular environment in a relatively short period of time, which consists of different reactions (Szewczuk (red.) 1989, p. 198).

1 The publication financed by the funds of the National Science Centre, Poland (project no. 2014/15/D/HS4/01170).

2 In the context of psychology, there is a definition of behavior. The behavior is defined as the result of action of external stimuli ( behavioral psychology), the result of actions instincts, determined by previous experiences and largely unconscious (psychoanalysis), the result of the needs of exploration and cognitive processes (cognitive psychology), the result experienced acceptance (humanistic psychology), communication remaining in the feedback, both a cause and a consequence (systems psychology), or attempt to adapt the organism to survive (evolutionary psychology). 
Human behaviour is significantly affected by a variety of factors, both internal and external. The most important ones include: personality-related factors, the nature of organisational environment and socio-cultural determinants of the external environment. It is therefore a process which is particularly complex and difficult to analyse theoretically (Penc 2007, p. 57).

Human behaviour in an organisation is therefore a function of the characteristics of the particular organisation, its processes, personal traits of members of the organisation, as well as the relationships that exist between the enterprise and its participants (Terelak 1999, p. 13).

General behaviour of an individual is subjectively rational. People focus primarily on themselves and on the consequences of their actions. It seems that in a crisis in an enterprise, its manager will try to first of all make supposedly right decisions. Mindful of the fact that the steps taken often determine the fate of the enterprise and realising how much responsibility rests upon its manager, such a person should act rationally.

People's behaviour is calculative, i.e. focused on maximising satisfaction. Most of the actions that a person takes are oriented towards minimising effort and personal cost while maximising benefits. In a crisis situation, difficult both for employees and managers, it seems that the manager should take actions the results of which will turn out to be - in this person's opinion - the best.

Behaviours can also be directed at other people or focused on selffulfilment. It seems that the manager of an enterprises in crisis by taking a number of anticipatory measures does everything possible to overcome this difficult situation. The manager realises, however, that a lack of effectiveness of actions taken, and thus the failure to lead the enterprise out of the crisis, may result in its collapse. Then the manager's (and the employees') job situation will significantly worsen. However, bearing in mind that a crisis in an enterprise can be a positive phenomenon (an incentive to take steps that the enterprise would not dare to take in the situation of stabilisation), it can be definitely said that this is an action focused both on others (employees do not lose their jobs) and the manager's self-fulfilment. A crisis is in fact often an opportunity to test the manager's knowledge, skills and competences.

Human behaviours are often focused on cooperation or competition, less often on maintaining a neutral position. They are shaped and modified directly by employee groups, organisational norms, patterns of behaviour and values. A person socially rooted in an organisation takes into account in his or her behaviour the principles found in the group of employees and the 
axio-normative system of the given enterprise ${ }^{3}$ (Sikorski 1999, Szumilak 2007, p. 11-12).

Unfortunately, in crisis situations, often they take the form of disorganized behavior.

Hence it is so important that an enterprise should have procedures for dealing with a crisis situation developed, and managers as well as employees of the organisation should receive regular training in this field. Only then, in a crisis situation, managers will know what to do and will receive the necessary support from their employees.

Taking any remedial measures by the management is a result of adopting the right attitude. It seems that the attitude of the enterprise's managers to the crisis phenomenon can be summarised in 8 different reactions (table 1).

Table 1. Attitudes of managers towards a crisis in their enterprise

\begin{tabular}{c|l}
\hline $\begin{array}{c}\text { Type of defence } \\
\text { mechanism }\end{array}$ & \multicolumn{1}{c}{ Attitude } \\
\hline Denial & A crisis happens to others, our enterprise is immune to a crisis. \\
\hline Rejection & Crises happen, but their impact on our organisation is minimal. \\
\hline Idealisation & Crises do not happen to good organisations \\
\hline Megalomania & The size and strength of our enterprise protects it from a crisis. \\
\hline Projection & If a crisis occurs, it means that someone has done harm to our enterprise. \\
\hline Intellectualisation & There is no need to worry about a crisis as long as its probability is low. \\
\hline Fragmentation & $\begin{array}{l}\text { A crisis cannot touch all parts of our organisation as long as they are } \\
\text { independent and separate. }\end{array}$ \\
\hline Confirmation & $\begin{array}{l}\text { A crisis happens to even the best-managed organisations. If it has happened } \\
\text { to us, we need to deal with it and draw lessons for the future. }\end{array}$ \\
\hline
\end{tabular}

Source: Walecka 2012, p. 159

3 The issues associated with human behaviour in an organisation are more widely presented in: Berelson, Steiner 1964; Bauer, Erdogan 2012; Januszkiewicz et al. 2012; Kożusznik 2014; Sikorski 1999; Clarke 2005; Kuc, Moczydłowska 2009.

61 
As the table above shows, very often managers of organisations in crisis do not believe in the existence of a crisis, or are not fully aware of its consequences. By adopting the attitudes ranging from denial to fragmentation, they hide behind "external forces" that damage the enterprise, idealise their organisation (and themselves as managers), or even reject the very possibility of a crisis. Taking any remedial action in a crisis situation in an enterprise must be preceded by the adoption of the attitude of confirmation. Only when managers accept that their enterprise is in crisis, they can start to act. This requires great humility on the part of managers, as well as a certain ability to admit defeat, since, as the literature shows, the most common causes of crisis lie within the organisation (Zelek 2003, p. 51; Podgórecki, 1969, p. 24; Kaplan 2000, p. 36; Drucker 1994, p. 106; Nogalski, Macinkiewicz 2004, p. 23; Urbanowska-Sojkin, 1999, p. 22; Booth 1993, p. 93 et al).

Specific actions taken by managers in times of crisis are a manifestation of certain attitudes and behaviours on their part. As already mentioned, these actions may vary. In terms of their intensity, they may be radical or conservative. From the point of view of their direction, they may include: reactive actions, centred around overcoming the effects of the past, and proactive actions, comprising measures aimed at creating conditions for the development of the enterprise (Wawrzyniak 1999, p. 73) ${ }^{4}$.

\section{Determinants of behaviour displayed by managers of enterprises in crisis}

The type of actions taken by managers in a crisis situation depends on many factors. Due to the complexity of these factors and their diverse impact on managers' behaviour, an attempt was made to build a model determining the behaviour of the management in crisis. The model is presented in figure $1^{5}$.

4 Reactive adaptation of the organisation to the environment, according to this author, means addressing the effects of the organisation's past. Proactive actions are attempts to adapt quickly in order to look towards the future and create new strengths of the organisation. In terms of reactive actions of the organisation, the author distinguishes two strategies: reorganisation and withdrawal. Proactive actions include: the investment strategy and consolidation.

Another division was made by M. Romanowska (2015, p. 33), who presented a classification taking into account continuous and discontinuous changes in the environment as well as various responses of an enterprise to a crisis (ignoring discontinuity, permanent adjustment, strategic breakthroughs, stepwise streamlining of the organisation).

5 The model does not include the impact of individual factors. It will be presented in a separate paper. 
It seems that factors determining the behaviour of managers in a crisis situation in their enterprise can be divided into (the author's own compilation):

- external factors (including factors that belong to the macro and microenvironment of the organisation),

- internal factors (the environment of the organisation, its culture, identity and employees, as well as the enterprise's material resources),

- factors related to the managers themselves, their state of mind, personality type, temperament, etc.,

- factors related to the crisis (its origins, the causes of the crisis, its type and phase).

External determinants are often the source and cause of a crisis in an organisation. Due to their large number, a wide range, complexity, and permanent changes, they are a difficult subject of study and analysis. Different groups of external factors affect enterprises with a varying strength. Depending on the sector, the enterprise's potential and its ability to adapt to new conditions, the same changes in the macro-environment may have different effects. Therefore, managers of enterprises in crisis should primarily verify the mission and strategic goals pursued by their enterprise. One should seek in the external environment such elements that can be used to one's advantage. Although the author of the paper is aware that managers have no control over many factors related to the macro-environment, they may adapt their strategy to the changing environment. It is important that enterprises in crisis should actively respond to the information derived from the macroenvironment, predicting, recognising and classifying it as an opportunity or a threat of to the enterprise's activity.

Interactions occurring in the micro-environment of the organisations, made up of specific phenomena, processes and entities that have a direct impact on the enterprise, are easier to predict and actively shape. At the same time, they are also the object of its influence.

The following have the greatest influence on the behaviour of managers of enterprises in crisis: competitors, customers, suppliers and owners. Competition provides an impetus for change in a market economy. Any enterprise that wants to grow in the market must be better than its competitors. Organisations that do not grow begin to decline.

Therefore, the manager of an organisation in crisis must keep in mind that the continuous monitoring of the environment and actions of competitors, as well as skilful management of all resources, are necessary in a crisis situation occurring in the enterprise. 


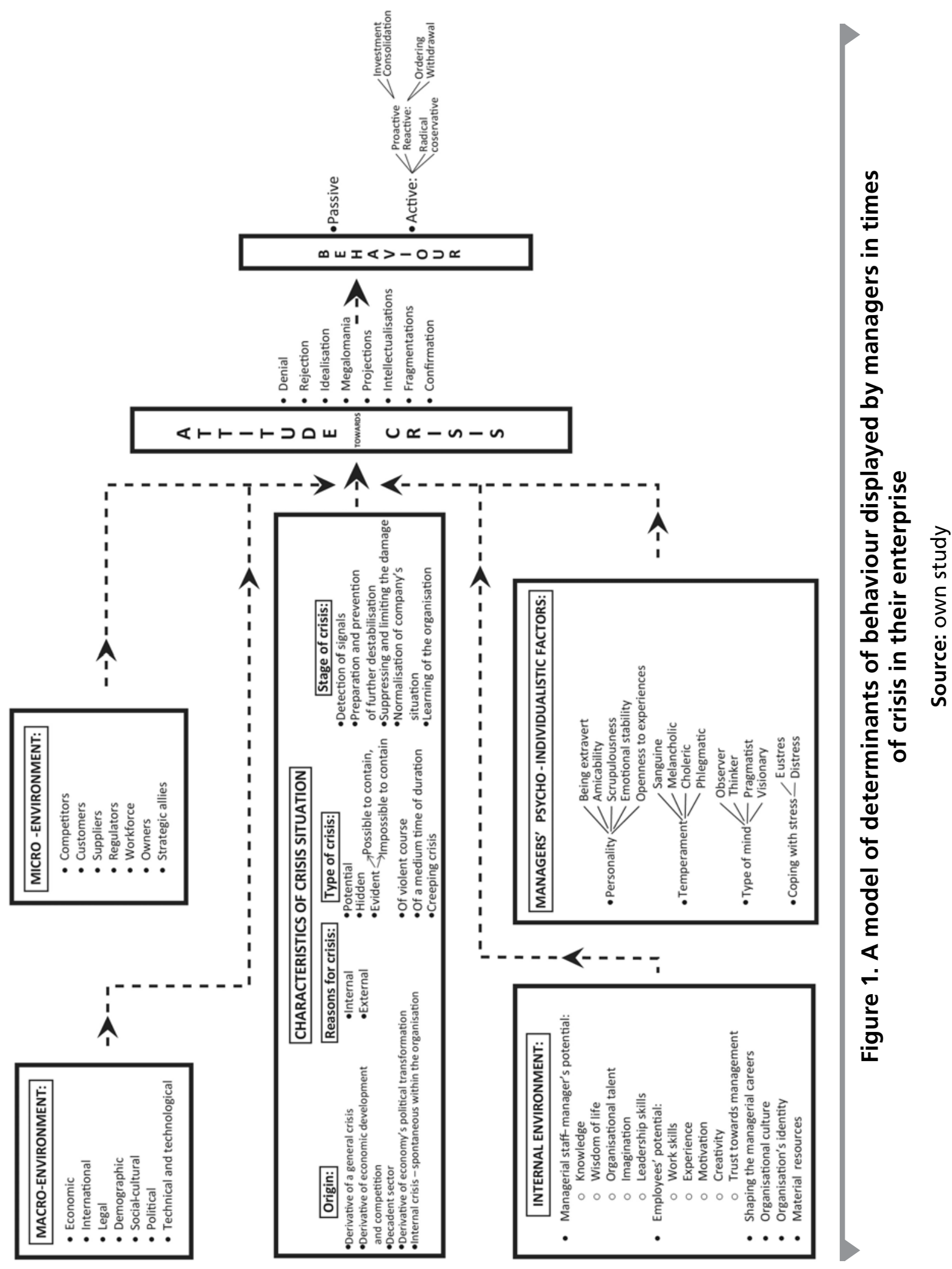

Determinants of managers' behaviour in a crisis situation in an enterprise - an attempt at model construction 
In today's world, customers play an increasingly important role in determining the fate of enterprises. Their needs grow constantly and their preferences become more and more individualised. They must therefore become the object of careful observation of the management of enterprises in crisis. If the effects of the crisis are visible to the average customer, managers of such organisations undoubtedly need to reckon with the possibility of adverse actions on part of customers.

Customers can also use all kinds of pressure on an enterprise in crisis, thereby preventing the management from taking appropriate remedial action.

Actions undertaken by the management are also affected by suppliers. Often in times of crisis an enterprise has financial problems. If a company supplying the enterprise with goods and services required for its operations, fearing for its own survival, withdraws from cooperation, or changes its terms, it can paralyse the functioning of the organisation. Therefore, managers of organisations in crisis should in advance take care of proper relations with suppliers. They should secure a diversification of supplies so that an adverse action of one of their suppliers should not prevent continued operation of the said enterprise.

Undoubtedly, taking appropriate remedial actions will be difficult for managers of organisations in crisis without significant support of business owners, who often have a different approach to the functioning of the enterprise. Business owners sometimes put their own interests above the interests of the enterprise and evade responsibility for its development (Lachiewicz, Walecka 2009).

Company owners are focused on deriving profit from its operations. This cannot, however, be an element that has an impact on basic activities of managers. The occurrence of a conflict between the owners and the senior management of the organisation in crisis causes a number of consequences, positive (e.g.: finding more favourable arrangements and making more appropriate decisions) but, above all, negative, causing crisis phenomena or difficulties in dealing with such phenomena.

Operational efficiency of enterprises and the threat of a crisis depend not only on external factors, but also to a large extent on activities and processes within the enterprise (endogenous factors). The paper details the elements of the environment within the enterprise (such as managers and employees of an organisation in crisis, the culture and the identity of the organisation or material and financial resources), as well as personality traits of managers.

In a crisis situation in an enterprise, the potential of its managers is extremely important. Their behaviour in a crisis will depend largely on their skills and knowledge. The public (employees of the enterprise and participants of the crisis situation) should be informed about the crisis. Only then all remedial steps can 
make sense. True leaders of enterprises in crisis should be characterised by the ability to positively interpret crisis situations and to draw meaningful conclusions from even the most unpleasant experience. The success of managers in a crisis situation depends largely on the extent to which they are able to reconcile innate and developed personality traits with the expectations of their superiors and subordinates, as well as with changes in the management situation arising from external circumstances.

The manner in which managers cope with a crisis also depends on the support of the actions taken by employees - internal crisis stakeholders (Walecka, Matejun 2009, p. 178). Employees are generally the group most directly affected by a crisis. Therefore, the phenomenon of negative attitudes on the part of employees emerges in a crisis situation. This attitude manifests itself in internal resistance (active or passive), for example, against planned changes in the enterprise. This resistance stems mainly from a diminished sense of security among employees and increased uncertainty as to their future.

Employees in a crisis situation in an enterprise can remain passive and refrain from any activities contributing to overcoming negative phenomena. Employees actively expressing their resistance to change go somewhat further. Not only do they not contribute to overcoming the crisis in the organisation, but they also take actions impeding or preventing managers from making changes related to the crisis situation. Therefore, it is extremely important that managers should be able to identify and overcome negative attitudes of their employees. This is connected with the need to develop an appropriate plan of action and the use of proper tools. The appropriate information policy plays a special role in this regard.

The above-presented descriptions indicate that various factors have a different impact on the behaviour of managers in enterprises in a crisis situation. Their relationship with the enterprise and the possibility of having an impact on it also vary. According to A. Zelek, the problem of differences and antagonisms existing between the interests of different groups can pose a potential threat to the smooth process of recovery of the enterprise (Zelek 2003, pp. 206-209). Therefore, the most important from the point of view of taking appropriate remedial actions by the management is identifying these groups of factors that are directly related to the crisis. They can be the cause of the given crisis situation, as well as the main recipients of negative effects of the crisis. No less important is the determination of the type of connections between the individual factors and the organisation. From the point of view of the needs and goals of remedial programmes, the most important are these groups of factors that are associated 
with the enterprise's financial relations (financial institutions, banks, creditors, etc.). In practice, the direction of the recovery process in an enterprise very often depends on the attitude and willingness of these groups.

All these determinants of managers' behaviour are crucial. However, the type of decisions that are made by managers of organisations in crisis will be largely a result of their personal qualities (the type of personality, temperament and mind, or the ability to respond to stressful situations $)^{6}$. No matter what pressure is exerted by various stakeholders in a crisis situation, managers can cope with this situation if they have strong personalities. Given the fact that a crisis situation in an enterprise is difficult for its manager and other stakeholders, actions taken by the management are accompanied by the state of permanently elevated levels of stress. Therefore, it seems that managers in a crisis situation should be generally self-confident. They will then be perceived as consistent in thought, words, actions and emotions. They will be easy to read by others and their behaviour will be seen as predictable and sustainable. Though their decisions may not necessarily please others, everyone will be aware of the fact that managers are doing everything to lead the enterprise out of the given crisis. This will be possible if the potential of the people they lead is activated. Managers build their own authority by respecting other people, constantly monitoring their own personalities and permanent learning, also from their own mistakes.

It should be noted, however, that any remedial actions taken by the management need to also derive from the very nature of the crisis (the causes of the crisis, its type and phase). Every crisis is a different situation in terms of decision-making. The manager will have to act completely differently in the sudden crisis situation and differently in the smoldering crisis situation. Different behaviour is required when the causes of the crisis lie outside the enterprise, and yet different when the reasons lie within it.

\section{Conclusions}

The type of actions that managers of enterprises in crisis take depends on many factors. These factors are associated with the enterprise itself, its resources and environment, as well as the nature of the crisis (its cause or type). Factors related to personal traits of managers are also important.

6 A detailed discussion of factors related to the personality of the manager of an enterprise in crisis is presented in: Walecka 2015. 
The response of managers to a crisis often depends on their ability to adapt to occurring events or circumstances. The determining factors in this case may include psychological factors such as self-confidence, willingness to take risks, or the ability to work under stress. Previous experience in working under pressure is among the factors affecting resistance to stress.

The behaviour of managers is also considerably influenced by the attitude of other people who often feel threatened in a situation of crisis in an enterprise. They make various attempts to put pressure on managers or, on the contrary, present the attitude of passivity or resistance to any proposed projects.

No matter how stakeholders behave in a crisis situation, managers of organisations in crisis are required first and foremost to take effective action that will enable the enterprise to overcome the crisis. Therefore, finding a proper, effective way out of the crisis will require taking the right decisions by managers.

\section{Summary}

Determinants of managers' behaviour in a crisis situation in an enterprise - an attempt at model construction

A crisis in an enterprise is an extremely difficult situation which company managers need to deal with. The enterprise may take all kinds of remedial actions. Ranging from conservative measures, through moderate to very radical ones. These steps may be aimed at counteracting the effects of the past or focused on looking towards the future of the organisation.

The type of actions that managers take depends on many factors discussed in the paper. These factors result from the organisation's external and internal environment, the nature of the crisis, as well as the manager's personality. The paper proposes an original model of determinants of managers' behaviour in a crisis situation.

Keywords: crisis in the enterprise, managers'behaviour, determinants of behaviour.

\section{Streszczenie}

Uwarunkowania zachowań kadry kierowniczej w sytuacji kryzysu w przedsiębiorstwie - próba budowy modelu

Kryzys w firmie jest niezwykle trudną sytuacją, z którą kadra kierownicza przedsiębiorstwa musi sobie poradzić. Może ona podjąć różnego rodzaju kroki zaradcze. Począwszy od kroków zachowawczych, umiarkowanych, na bardzo radykalnych 
skończywszy. Kroki te mogą być skierowane na niwelowanie skutków przeszłości, bądź wychodzące w przyszłość organizacji. To, jakiego rodzaju działania menedżerowie podejmą, zależy od wielu czynników, omówionych $w$ niniejszym opracowaniu. Są to czynniki, wynikające $z$ otoczenia organizacji, jego wnętrza, charakteru samej sytuacji kryzysowej, czy osobowości menedżera. $\mathrm{W}$ opracowaniu zaproponowano autorski model determinant zachowań kadry kierowniczej w kryzysie.

\section{Słowa}

kluczowe: kryzysw przedsiębiorstwie, zachowania kadry kierowniczej, determinanty zachowań.

\section{References:}

1. Bauer T., Erdogan B. (2012), An Introduction to Organizational Behavior, http:/ /2012books.lardbucket.org (access: 15.02.2015).

2. Berelson B., Steiner G.A. (1964), Human Behavior, New York.

3. Booth S.A. (1993), Crisis Management Strategy. Competition and Change in Modern Enterprises, Routledge, London.

4. Clarke D. (2005), Zachowania prospołeczne i antyspołeczne, Gdańskie Wydawnictwo Psychologiczne, Gdańsk.

5. Drucker P.F. (1994), Praktyka zarzadzania, Wydawnictwo Akademii Ekonomicznej w Krakowie, Kraków.

6. Januszkiewicz K. i zespół (2012), Zachowania ludzi w organizacji. Uwarunkowania i kierunki ewolucji, Wydawnictwo UŁ, Łódź.

7. Kaplan R. (2000), Balanced Scorecard, Europejski Instytut Rozwoju Regionalnego i Lokalnego, Warszawa.

8. Kożusznik B. (2014), Zachowania człowieka w organizacji, PWE, Warszawa.

9. Kuc B.R., Moczydłowska J.M. (2009), Zachowania organizacyjne, Difin, Warszawa.

10. Lachiewicz S., Walecka A. (2009), Rola naczelnego kierownictwa w sytuacji kryzysu w przedsiębiorstwie, [in:] Zarządzanie organizacja w nowej rzeczywistości gospodarczej - CD publication - ISBN 9788360200780.

11. Malewska K. (2003), Strategie zarządzania kryzysem w przedsiębiorstwie, [in:] J. Skalik (ed.), Zachowania organizacji wobec zjawisk kryzysowych, Cornetis, Wrocław.

12. Nogalski B., Macinkiewicz H. (2004), Zarządzanie antykryzysowe przedsiębiorstwem. Pokonać kryzys i wygrać, Difin, Warszawa.

13. Penc J. (2007), Zachowania i uczestnictwo ludzi w organizacji, [in:] E. Jędrych (ed.), Zarządzanie zasobami ludzkimi dla menedżerów średniego szczebla, Oficyna a Wolters Kluwer business, Kraków. 
14. Podgórecki A. (1969), Patologia życia społecznego, PWN, Warszawa.

15. Robbins S.P., Judge T.A. (2011) , Zachowania w organizacji, PWE, Warszawa.

16. Romanowska M. (2015), Kryzys w przedsiębiorstwie, [in]: M. Romanowska, W. Mierzejewska (eds.), Przedsiębiorstwo odporne na kryzys, Oficyna a Wolters Kluwer business, Warszawa.

17. Sikorski Cz. (1999), Zachowania ludzi w organizacji, PWN, Warszawa.

18. Starosta A. (2014), Anti-crisis Management Strategies. The case of companies in the Greater Poland Voivodeship, "Management" Vol. 18.

19. Szewczuk W. (ed.) (1989), Stownik psychologiczny. Wiedza Powszechna, Warszawa 1989.

20. Szumilak J. (2007), Racjonalność zachowań nabywców ustug turystycznych w aspekcie gospodarowania informacja, „Folia Touristica” No. 18.

21. Terelak J. (1999), Psychologia menedżera, Difin, Warszawa.

22. Tomaszewski T. (1982), Podstawowe formy organizacji i regulacji zachowania, [in:] T. Tomaszewski (ed.) Psychologia, PWN, Warszawa.

23. Urbanowska-Sojkin E. (1999), Zarzadzanie przedsiębiorstwem: od kryzysu do sukcesu, Wydawnictwo Akademii Ekonomicznej w Poznaniu, Poznań.

24. Walecka A. (2012), Postawa menedżera w sytuacji kryzysu w przedsiębiorstwie studium przypadku mikroprzedsiębiorstwa, [in:] P. Wachowiak (ed.), Człowiek w organizacji. Teoria i praktyka. Oficyna Ekonomiczna SGH, Warszawa.

25. Walecka A. (2014), Managers' Behaviour Determinants in the Enterprise Crisis Situation, Lodz University of Technology, A Series of Monographs, Łódź.

26. Walecka A. (2015), Osobowość kadry kierowniczej przedsiębiorstw w kryzysie próba budowy modelu, "Marketing i Rynek", No. 5.

27. Walecka A., Matejun M. (2009), Postawy pracowników wobec sytuacji kryzysowej w organizacji, [in:] S. Lachiewicz, A. Zakrzewska-Bielawska (ed.), Zarzadzanie organizacjami w warunkach konkurencyjnej gospodarki, Wydawnictwo Politechniki Łódzkiej, Łódź.

28. Walecka A., Zakrzewska - Bielawska A. (2009), Strategie antykryzysowe i modele zarządzania przedsiębiorstwem w kryzysie, [in:] J. Bieliński, R. Płoska (ed.), Przedsiębiorstwo w warunkach kryzysu, Prace i Materiały Wydziału Zarządzania Uniwersytetu Gdańskiego, Sopot.

29. Wawrzyniak B. (1999), Odnawianie przedsiębiorstwa. Na spotkanie XXI wieku, Poltext, Warszawa.

30. Wawrzyniak B. (ed.) (1984), Zarzadzanie w kryzysie. Koncepcje, badania, propozycje, PWE, Warszawa.

31. Zakrzewska - Bielawska A. (2008), Zarządzanie w kryzysie, [in:] I. Staniec, J. Zawiła - Niedźwiecki (ed.), Zarzadzanie ryzykiem operacyjnym, Wyd. C.H. Beck, Warszawa.

32. Zelek A. (2003), Zarządzanie kryzysem w przedsiębiorstwie - perspektywa strategiczna, Instytut Organizacji i Zarządzania w Przemyśle "Orgmasz", Warszawa.

33. Zimbardo P.G. (2005), Psychologia i życie, PWN, Warszawa. 